\title{
“There is no other way than collaboration!"
}

\author{
Não há outro caminho que não a colaboração!
}

“No hay otro camino a no ser la colaboración!”

\author{
ANDRÉ LUIS NOGUEIRA DA SILVA ${ }^{12}$ \\ ${ }^{1}$ Fundação InStituto Brasileiro de Geografia E Estatística (IBGE), NATAL - RN, BRAZIL \\ 2 Fundação Getulio VARgas (FGV EAESP) / SÃo PAUlo SCHOOl of Business AdMINISTRATION, SÃo PAULO - SP, BRAZIL
}

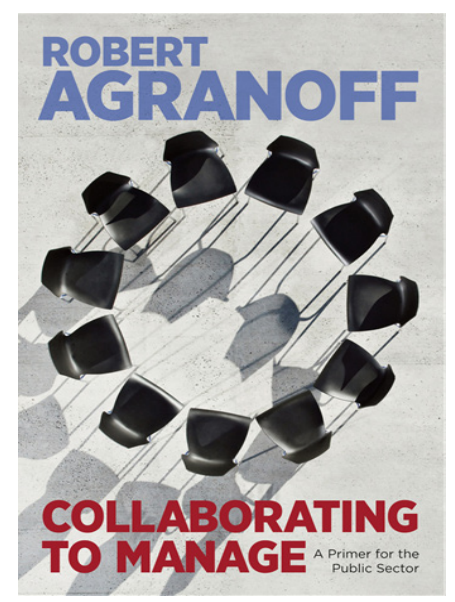

AGRANOFF, R. Collaborating to manage: a primer for the public sector. Washington: Georgetown University Press, 2012. 270 p. ISBN 978-1-58901-916-4.

Keywords: Collaborative management. Public administration. Public agencies.

Palavras-chave: Gestão colaborativa. Administração pública. Agências públicas.

Palabras clave: Gestión colaborativa. Administración pública. Agencias públicas.

There is no other way than collaboration! This is the main challenge facing the public sector today, according to Robert Agranoff (2012). In this work, which proposes theoreticalpractical, the political scientist embarks on the field of contemporary public management, incorporating not only his trajectory of research on intergovernmental relations but also bringing an important contribution from network theory and business administration itself. His main argument is that collaborative management is the newest and emerging way to solve collective problems and, thus, of giving resoluteness to public agencies in the face of the fast demands that arise in the globalized and interactive world.

The book is anchored in the idea that there are problems so intractable, so difficult to solve, that the ways to strike them are unknown, complex or need the action of multiple actors, including private ones, to be solved. The concept of collaborative management appears, then, as a theoretical-practical definition for understanding the process of managing public enterprises - policies or programs - that advocate joint action. Agranoff (2012) describes it as the process of facilitating and operating resources in multiorganizational arrangements to deal with collective problems, which cannot be resolved by the performance of organizations in isolation. It is a more comprehensive definition than the collaborative governance perspective proposed by Ansell and Gash (2007), which, while also emphasizing the participation of different actors in the management of public policies, conceives only formal decision-making arrangements. By gathering basic elements of collaborative management, the author seeks to contribute not only to the academic debate, but also to help public managers to deal with the problems they face in their daily lives. This objective frames the narrative structure and the language adopted by the author, who chooses to start all 9 chapters of the book with the presentation of a specific case. According to Agranoff (2012, p. 1), "The book should not be read as an operating manual but as a way to link thought to action".

Chapter 1, "Managing is collaborating", presents the objectives and justification of the book, explaining its theoretical and conceptual premises and building a synthesis of the other parts of the text. Agranoff (2012) indicates 3 studies that constitute the knowledge base about collaboration as an administrative practice. The first is Wagenaar (2004), about interactive bureaucracy, which characterizes administrative transactions as: a) situated; b) surrounded by knowledge; c) actions; d) developed through interaction between the parties. The second is Keith Sawyer (2007), who addresses the creative power of collaboration. In his research, Sawyer (2007) concluded that engaging in collaborative efforts provides greater creativity, which originates when people work together in a situation with peak activities. Finally, the third study brings the concept of 
interoperability as a relevant theoretical dimension of collaborative management. Jenkins' (2006) work demonstrates that reciprocal communication between the operational and planning sectors is a key element to "unlock" the collaboration process.

Regarding conceptual aspects, Agranoff (2012) highlights the existence of a mix of collaborative activities, which can vary from weaker and more fluid connections to more permanent structural arrangements. These connections can occur legally or informally. The author also categorizes the types of collaboration based on 2 variables: a) the level of engagement of the parties (minimum and maximum); b) the frequency of interaction (intermittent or regular). He warns, however, that this classification is more useful to demonstrate that there are different types of collaboration. Furthermore, it reveals different ways of using synergy as logic for joint action. The concepts of conductive organizations and networks are also used as essential to understanding collaborative management, so much so that they are further developed in chapters 3 and 6 , respectively.

Chapter 2, "Intergovernmentalization and collaborative public management", demonstrates how intergovernmental relations deepened the need for collaboration. Agranoff (2012) states that intergovernmental management does not only involve different levels of government but also encompasses different governmental and non-governmental actors. Collaboration, therefore, presupposes vertical and horizontal, state and non-state interactions:

Collaborative management thus begins with a basic understanding of the structures and interdependencies in the system. Programs and delivery organizations exist in a complex array of opportunities that, if combined and/or connected, can work at solving some of society's most intractable problems (AGRANOFF, 2012, p. 50)

The next chapter addresses an essential concept for collaborative management: the conductive public agency. Saint-Onge and Armstrong (2004) understand that an organization is conductive when able to guarantee the quality of its services and maintain the flow of knowledge even in a scenario of constant change and adaptation to the needs of customers and the market. For this, the organization must create partnerships, build alliances and perform its team so that they act across organizational and functional boundaries. Agranoff (2012) believes that this concept can be transmuted to the public sector, stating that it is increasingly necessary for public organizations to be more permeable to the external environment. Intergovernmentalization, the proliferation of new governance tools and increased interaction with the third sector and the private sector imply the need to increase the conduct of public agencies.

In chapter 4, "Forging external agreements", the author's concern falls on the cooperative devices signed with entities external to the government, such as non-governmental organizations (NGOs). Analyzing this tool - management contracts, grants, and multiparty agreements -, Agranoff (2012) points out that its constitution involves a series of activities that take place outside the public agency and across organizational boundaries. Negotiating awards for achieving goals, interpreting and informing objectives and rules, providing technical assistance and building networks are some of the activities that are part of the conductive agency's routine.

Managing conductive agency connections assumes counterparts between the parties. This is the opening motto of the next chapter, "Managing agency connections". Its focus is to deepen the issue of interaction between conductive agencies and the organizations with which they work. Agranoff (2012) rescues studies on the implementation of public policies to address the operational issue of collaborative ventures. It brings, then, the notion of interoperability, claiming to refer to "[...] regularized programming involving two or more entities for which operating policies and processes have been articulated and are executed interactively to some considerable degree" (AGRANOFF, 2012, p. 122). The general idea is that important decisions are made until the actual delivery of public services. Often, in the course of planning until the implementation of these policies, different entities are involved, whether public, private or from the third sector. This maximizes the importance of ensuring that such cooperative arrangements have interoperable management.

Considering that the constitution of public policy networks is the highest collaborative level, the author devotes a chapter to the specific approach of managing these arrangements. "Processing deeping collaboration: managing in network" deals with the operational process of networks, demonstrating that, despite their self-organizing character, they also need leadership. Public managers are responsible for promoting their management, whose main challenge is to accommodate the different interests and provide synergy in achieving the objective for which they were created. For Agranoff (2012), networks share the following characteristics: a) identifiable and / or permanent status; b) regular meetings; c) definable communication system; 
d) have leaders and participants; e) constitute task forces or working groups; f) have a governance structure; g) have specified partners; h) have some form of division of labor or allocation of tasks.

Chapter 7, "Identifying and overcoming barriers to collaboration", discusses possible failures in collaborative management and outlines ways to try to avoid them. The author identifies 7 impediments to collaboration: a) protection of the institution's domain/territory; b) risk aversion; c) loss of time and opportunity cost; d) multicultural and multiorganizational nature of potential participants; e) effort of power; f) retention of previously agreed resources; g) specific barriers of certain public policies. The main way to overcome such obstacles would be to build trust, which can be consolidated by the institution of participatory deliberation processes and by the fulfillment of agreed commitments.

Chapter 8, "The new public organization", thus presents a bureaucratic organization that is widely conductive, an organizational structure that is open and capable of moving and articulating at different borders. It's able to mobilize efforts, actors and entities to achieve its objectives and, mainly, to solve intractable problems, impossible to be solved by a single organization. The use of digital tools, the deepening of civic engagement, the focus on the use of knowledge in decisionmaking, joint learning and, above all, the network organization are elements that demarcate this new configuration of government agencies. Rigidity and isolationist hierarchy give way to fluidity, dynamism and, in particular, uninterrupted collaborative processes.

"Collaboration works!" is the chapter that closes the book and the title itself denotes its normative bias. Before arguing in favor of collaborative management, Agranoff (2012) puts collaboration as a strategy to act in an increasingly interconnected world, marked by the continuous complexification of social and institutional relations. A world in which the need for change does not end and, as a consequence, requires organizations, whether public or private, greater agility to respond to demands that arise quickly and, often, spontaneously. It is these contemporary or macro-structural issues that lead to the transition from an era of control to a world of adaptability. It is about the exhaustion of the classic theories of administration, whose substrate is found in the Fordist, Taylorist and Weberian models, and the transition to a new paradigm, based on networks, information and collaboration, whose brand are open boundary organizations. This new era does not imply the emptying of the power of public bureaucracy. On the contrary, it demands a repositioning of its functions, aiming to add public value to its performance.

Thus, the book offers a new look at the dualism between private administration and public administration, a debate initiated in a classic text by Woodrow Wilson (1887) and always present when the subject is the reform of the State (ABRUCIO, 1998). Despite the differences, Agranoff (2012) finds in the procedural analysis and the globalizing conditions a conceptual bridge: collaboration. Demystifying the existence of a rigid duality, he demonstrates that the two fields of study must help both in practical terms and in the development of theoretical and methodological instruments. When Agranoff (2012) brings the notion of collaboration as a pressing condition, even to the world of business organizations, where competition is commonly raised as a substrate of origin and survival, it contradicts the political science literature that conceives the process of aggregating preferences as a zero-sum game. The studies and the success stories it presents show that it is possible to mobilize entities with different interests to work towards common goals. For the author, collaborative public management is not only possible but also the only way to solve complex contemporary problems. 


\section{REFERENCES}

ABRUCIO, F. L. Os avanços e os dilemas do modelo pós-burocrático: a reforma da administração pública à luz da experiência internacional recente. In: BRESSER-PEREIRA, L. C.; SPINK, P. (Org.). Reforma do Estado e administração pública gerencial. Rio de Janeiro: Ed. FGV, 1998. p. 173-199.

AGRANOFF, R. Collaborating to manage: a primer for the public sector. Washington: Georgetown University Press, 2012.

ANSELL, C.; GASH, A. Collaborative governance in theory and practice. Journal of Public Administration Research and Theory, v. 18, n. 4, p. 543-571, 2007.
JENKINS, W. O. Collaboration over adaptation: the case for interoperable communications in homeland security. Public Administration Review, v. 66, n. 3, p. 319-322, 2006.

SAINT-ONGE, H.; ARMSTRONG, C. The Conductive Organization. Amsterdam: Elsevier, 2004.

SAWYER, K. Group genius: the creative power of collaboration. New York: Basic Books, 2007.

WAGENAAR, H. Knowing the rules: administrative work as practice. Public Administration Review, v. 64, n. 6, p. 643-655, 2004.

WILSON, W. The study of administration. Political Science Quarterly, v. 2, n. 2, p. 197-222, 1887. 